mønstrene er ikke stabile slik vi trodde, skriver Torgersen. En så viktig observasjon bør begrunnes bedre enn ved å vise til avbleking med aldring og til at mønstrene kan influeres av symptomlidelser og belastninger. Torgersen forsøker å konkretisere konsekvensene av personlighetstyper i hverdagen ved å beskrive samspill i parforhold. Han har, skriver han på side 153, valgt litt ekstreme eksempler som ligger nær opp til våre kjønnsrollestereotypier. Hensikten er å tydeliggjøre mønstrene. Jeg prøveleste dette høyt for en kollegagruppe som reagerte mer med vantro munterhet enn med forståelse. Behandlingskapitlet er dessuten lite gjennomarbeidet. Den som ønsker å lære om dette, trenger en grundigere og mer fullstendig tekst.

Min samlede vurdering er derfor at boken hadde tjent på en mer omfattende revisjon. Gammelt tankegods kunne med fordel fjernes samtidig som nyere forskning kunne presenteres bredere - og kanskje med den kritiske analytiske tilnærmingen som tidligere har vært et av Torgersens varemerker.

Men for all del: Dette er fortsatt en spennende og kunnskapsrik innføring i og drøfting av personlighetens ulike dimensjoner og mønstre.

\section{Ny utgave av norsk lærebok i medisinsk mikrobiologi}

Degré M, Hovig B, Rollag $H$, red

Medisinsk mikrobiologi

3. utg. 803 s, tab, ill. Oslo: Gyldendal Akademisk, 2008. Pris NOK 795

ISBN 978-82-05-31590-7

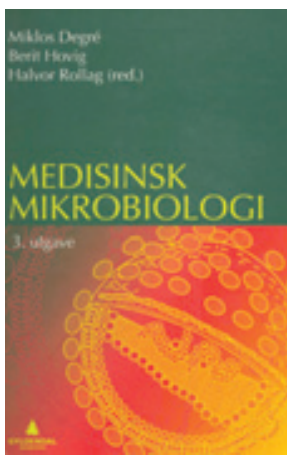

Dette er 3. utgave av en lærebok i medisinsk mikrobiologi som er beregnet på medisinstudenter. Den er skrevet av spesialister som har årelang erfaring i undervisning av legestudenter, har bred erfaring og oversikt over

faget og evner å formidle dette i sin bok

Faget medisinsk mikrobiologi er i rask utvikling, både fordi det stadig oppdages nye mikrober og ny kunnskap erverves om utbredelsen av smittestoffene. Dessuten skjer det en kontinuerlig utvikling innen mikrobiologisk diagnostikk og behandling av infeksjonssykdommer, slik at det nå igjen er påkrevd med en ny utgave av læreboken.

Den nye utgaven har samme oppbygning og de samme kapitlene som den forrige, som for øvrig var svært omarbeidet i forhold til førsteutgaven. Selv om ingen nye kapitler er kommet til siden sist, er det mye nytt stoff. Spesielt er de kapitlene som omtaler antibiotikabehandling oppdatert med nyheter innen antibakterielle midler, antiviralia og resistensutvikling.

Boken har mange tabeller og illustrasjoner som gjør stoffet lettere tilgjengelig, men har ingen fargebilder eller plansjer slik man kan finne i de fleste nyere lærebøker.

For de av leserne som ønsker å fordype seg i stoffet, er det i denne utgaven tatt med referanser til utdypende litteratur etter hvert kapittel.

En stor fordel med å lese en norsk lærebok i medisinsk mikrobiologi er at stoffet er tilpasset norske forhold. Utbredelsen av smittestoffer er svært forskjellig i ulike deler av verden, og fagstoff $i$ for eksempel en amerikansk bok kan ikke direkte overføres på norske forhold. Denne boken formidler kunnskap om de norske epidemiologiske forhold og vår kliniske praksis.

Utover målgruppen legestudenter, vil mange andre som interesserer seg for dette fagfeltet kunne ha nytte av å lese den.

\section{Susanne Gjeruldsen Dudman}

Avdeling for virologi

Nasjonalt folkehelseinstitutt

\section{En ny Semmelweis?}

Kendrick M

\section{Det store kolesterolbedraget}

Hva gir deg egentlig hjertesykdom - og hvordan unngår du det? $267 \mathrm{~s}$, tab, ill, Oslo: Forlaget Lille Måne, 2008. Pris NOK 329

ISBN 978-82-92605-60-8

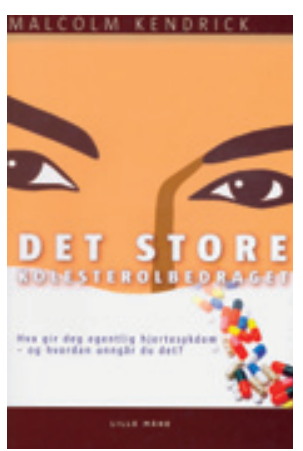

Forfatterens målgruppe synes å være alle, både leg og lærd, som er blendet av at kolesterolhypotesen nå er bevist etter ca. 100 års forskning. Selv om boken også henvender seg til ikke fagorienterte, tror jeg at lesere uten god basal kunnskap i lipidmetabolisme og hjerte- og karsykdommer vil ha problemer med å følge forfatteren og hans argumentasjon gjennom de 11 kapitlene og 267 sidene. Et forord er forfattet av spesialist i radiologi Tor Ole Kjellevand og et etterord av Dag Viljen Poleszynski, fagredaktør i Mat \& helse. Boken er godt oversatt av Tone Bøstrand.

Boken har stive permer og enkle relevante illustrasjoner. De første 200 sider og åtte kapitler er et systematisk angrep og forsøk på å bortforklare det som ligger til grunn for at majoriteten av forskere i dag vil hevde at kolesterolhypotesen er bevist.

Teksten på smussbindet forteller at forfatteren $\mathrm{i}$ en strålende opplagt form og bitende skotsk humor, bevæpnet med (etter egen oppfatning) faktakunnskap setter nådestøtet mot det rådende kolesterolparadigmet og tilbakeviser mytene om hva som forårsaker hjertesykdom. Avsløringer om de tette økonomiske båndene som eksisterer mellom den farmasøytiske industrien og legevitenskapen, understreker ifølge forfatteren hvorfor statiner ikke har noen plass i dagens medisin.

Forfatteren prøver å vise at mettet fett $i k k e$ øker kolesterolnivået i blodet, at kolesterol ikke tetter blodårene og at statiner ikke senker kolesterolnivået og gir liten eller ingen beskyttelse mot hjerte- og karsykdommer. Teksten på smussbindet lover at dersom «du er en av mange nordmenn (ca. 400 000, data fra SLV 2008) som daglig tar kolesterolsenkende medisiner (statiner) kan denne boken bokstavelig talt redde livet ditt». «Den skal gi deg kunnskapen du trenger for å sove godt om natten» ( . . og kanskje ikke våkne om morgenen?). Argumentene er fremført med stort engasjement, men jeg er prinsipielt uenig med påstanden $i$ forordet om at det Kendrick skriver er vitenskapelig dokumentert. Hvis så skulle være tilfellet, har norske helsemyndigheter, Helsedirektoratet, Statens legemiddelkontroll og Kunnskapsenterets forskjellige utvalg en jobb å gjøre med den konspirasjonbevegelse de har vært utsatt for. Jeg følte meg faktisk flere ganger hensatt til Ludvig Holbergs tekst og Erasmus Montanus' argumentasjon. Det skal ikke være plass for denne anmelderen til å forme en bokanmeldelse som et motinnlegg. Det var derfor med stor interesse jeg leste bokens siste tre kapitler med overskriftene: Hva er årsaken til hjertesykdom? Stresshypotesen - stemmer den med fakta? Andre former for stress. Her er faktisk forfatteren på linje med resultatene fra den store pasient-kontroll-studien INTERHEART som registrerte risikofaktorer for første hjerteinfarkt - og som omfattet totalt 27098 menn og kvinner. Men nå forsvinner risikofaktorer som røyking, hypertensjon, diabetes, abdominal overvekt, fysisk aktivitet, lipider (apo B/apo A1) og «high risk diet» (mettet fett) i Kendricks forklaring på årsaken til hjertesykdom. Statens Institut for Folkesundhet i Danmark har nylig beregnet hvor mye bl.a. stress og belastninger på jobben reduserer den forventede levetid: hos menn med fem år og hos kvinner med to år. Så stress betyr mye i Danmark men viktigere er røyking, fysisk inaktivitet, høyt blodtrykk, lavt inntak av frukt og grønt, for mye mettet fett bl.a. De samme risikofaktorer som i INTERHEART-studien. Det «glemmer» Kendrick i sin bok.

Boken kan ikke anbefales til hjertefriske eller hjertesyke pasienter, men til allmenn- 
leger og hjerteleger som ønsker å skaffe seg kunnskap om hva en gruppe «falske profeter» «har klart å innbille ikke bare legfolk, men også de fleste leger og andre som arbeider innen det offentlige helsevesen, regulerende myndigheter, medier og politikere». I Poleszynskis etterord loves det videre at boken er et viktig bidrag slik at vi skal forstå at kolesterol i blodbanen er farlig er en fatal feiloppfatning. Om ikke mange år vil trolig dette bli sett på som et kuriosum. Poleszynski betviler i etterordet at stress kan være primærårsak til hjertesykdom, men bare en sekundærårsak. Nå er forvirringen fullbrakt for anmelderen. Kendrick er ikke vår tids Semmelweis.

Jeg vil derfor anbefale Tidsskriftets lesere Daniel Steinbergs The cholesterol wars. The skeptics vs. the preponderance of evidence (1).

Leiv Ose

Lipidklinikken

Rikshospitalet

\section{Litteratur}

1. Steinberg D. The cholesterol wars. The skeptics vs. the preponderance of evidence. New York: Academic Press, 2007.

\section{Erfarings- og kunnskapsbasert kritikk av rusbehandling}

Andresen E.

Fri fra avhengighet

183 s. Oslo: Cappelen Damm, 2008.

Pris NOK 329

ISBN 978-82-02-27992-9

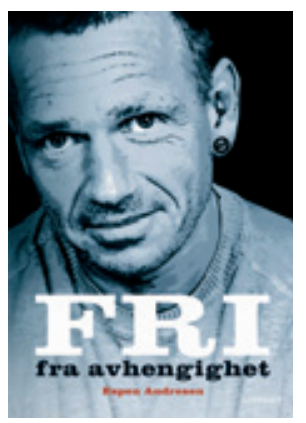

Forfatteren er tidligere rusklient og addiktolog Espen Andresen. Gjennom en åpen selvbiografi gir han oss et innblikk i sitt liv, sine opplevelser og ikke minst sine erfaringer som behandlingsmottaker. Han utdannet seg til behandler etter at han ble rusfri og har jobbet bl.a. på Veksthuset i Oslo, et sted han selv var klient noen år tidligere.

Andresen er meget kritisk til mange deler av behandlingen som tilbys rusavhengige i Norge. Han etterlyser et høyere kunnskapsnivå og sier rett ut at en del av det han selv ble tilbudt som klient, forverret hans avhengighet heller enn å hjelpe ham. Mange av de behandlerne han har møtt, hadde verken kunnskap eller forståelse nok om den avhengiges situasjon og tankesett til å bli annet enn medløpere i den sykes eller kriminelles ville ferd. Vi vet ikke hvor stor del av denne kritikken som er rettferdig, men leseren blir av og til sittende igjen med følelsen av at alle - uansett ståsted - har vært for dårlige, og man kan lure på om all skyld er like rettferdig fordelt. Kanskje er ikke dette så viktig, eller det kan være det $i$ en bok som skal fortelle om hva som virker og ikke virker innen behandlingen.

Boken åpner med en lignelse om dyr, mennesker og diamanter, og allerede der etableres en løfterik metafor og en positiv grunntone. Alle mennesker bærer en diamant i seg! Andresen åpner for et grunnleggende positivt menneskesyn og bevisstgjør et viktig potensial som alle har. Han innfører dertil flere begreper som «sterbing», «medavhengighet», «feilprogrammering» og «faser», som på mange måter hjelper oss til å forstå hans budskap bedre. Innimellom kan man ta seg i å undres om begrepene er nødvendige for å bringe innsikt. Andre ganger fungerer det godt.

Boken er på sitt beste når den er personlig. Når forfatteren forteller om sine vanskelige opplevelser, skriver han godt og vi blir revet med. De mer forklarende og pedagogiske avsnittene kan virke mer uinteressante, kanskje mest fordi det kan være vanskelig å gripe hva som menes.

Det er mange veier til sannhet, innsikt og frelse for den delens skyld. Det betyr ikke at alt er like bra og at ingenting skal kritiseres. Dette gjør det interessant å lese om Andresens vei, og mange av oss kan ha nytte av å lese hva han mener har fungert og ikke fungert. Der er boken givende. Som behandlere må vi tåle den støyten det er at noen mener noe annet enn oss og faktisk ikke liker den jobben vi gjør. Det vi synes er noe verre, er at en del andre rusavhengiges valg fordømmes i til dels sterke ord. Folk kan kanskje leve godt med andre valg enn dem Andresen har tatt, og selv innen hans univers må det være dumt å la det beste bli det godes fiende.

Men for all del, vi hadde en god og lærerik stund under lesingen. - av og til en øvelse i ydmykhet når man blir kritisert som verst og kjenner seg igjen i de «dårlige» behandlerne. Men en slik øvelse har man ikke vondt av, spesielt fordi det kan ligge forbedringspotensial i slikt. Ikke minst er Andresens egen historie om hvordan han selv fant «diamanten» i seg og klarte å utløse sitt eget potensial inspirerende. Vi kan trenge bøker fra «alt-ermulig-menn» fra rushelvetet. For hvis nesten alt til syvende og sist er mulig, ja da er også nesten ingenting umulig - heller ikke i rusrehabiliteringen.

\section{Jørgen G. Bramness}

Senter for rus og avhengighetsforskning Universitetet i Oslo

\section{Harald Sundby}

Kalvskinnet legesenter

Trondheim

\section{Flyktningbakgrunn - betydning for pasientbehandlingen}

Varvin S.

Flyktningpasienten

207 s. Oslo: Universitetsforlaget, 2008.

Pris NOK 279

ISBN 978-82-15-00879-0

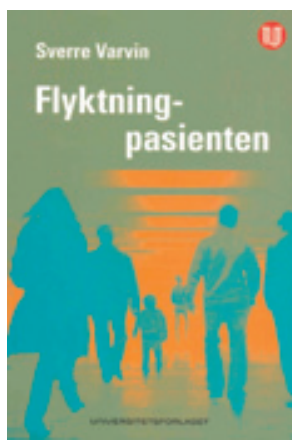

Boken behandler detaljert og seriøst et svært viktig og underkommunisert problem i det norske helsevesen og samfunnet ellers: det å være flyktning. Forfatteren sier at dette er en tvetydig situasjon, hvor flyktninger på den ene

siden bærer med seg virkninger av undertrykkelsen, forfølgelsen, de fysiske og psykiske overgrepene fra sitt hjemland, og på den andre siden havner i et fremmed land hvor de ble sett på som annerledes og møtt med fordommer og sosialt uvante krav. Med den psykologiske ballasten de har med seg møter de daglige utfordringer i forsøket på å tilpasse seg levesettet $i$ et nytt land. I grensesnittet mellom personlige muligheter og egne forventninger til å skape seg et nytt liv, vil mange av flyktningenes forestillinger om landet de er kommet til, bli forandret og skape problemer både personlig, i egne familier og i lokalsamfunnet. Noen er flinke til å søke hjelp, andre vet ikke at hjelpen finnes og hvor, slik at andre må identifisere problemene og formidle hjelpen. I slike situasjoner kreves det engasjement både av fastlegen, psykiatriske tjenester i helsevesenet, arbeidsstedet og andre sosiale nettverk for videre oppfølging.

Norge har ca. en halv million innvandrere i dag, og tallet kommer til å øke sterkt fremover, slik at det forventes mellom 1,1 og 2,6 millioner innvandrere $i$ år 2060. Det er kommet ca. 63000 innvandrere til Norge $i$ år 2007. Ved inngangen til 2008 bodde det 132400 personer med flyktningbakgrunn i Norge. De utgjorde 2,8 prosent av Norges befolkning. Flyktninger fra Irak og Somalia utgjorde de to største gruppene. Henholdsvis 17600 og 15500 personer har bakgrunn fra disse landene.

Til sammen bor det nå 132400 personer med flyktningbakgrunn i Norge. Av disse er nesten 100000 regnet som primærflyktninger, mens de resterende 32500 er innvandret ved familiegjenforening med primærflyktninger.

I løpet av 2007 økte antall personer med flyktningbakgrunn med 7200 personer. Den største økningen i løpet av 2007 var det personer med irakisk og somalisk landbak- 